\title{
The First Albanian Textbooks after World War II, and the Construction of the New Albanian Citizens
}

\section{Esmeralda Dani}

\author{
PhD Lecturer, Faculty of Education University of Shkodra; Email: esmeraldahoti@yahoo.it
}

\section{Rina Muka}

PhD Lecturer, Faculty of Education University of Shkodra; Email:gerarina@yahoo.com

\section{Doi:10.5901/ajis.2016.v5n2p101}

\begin{abstract}
The construction of the new Albanian citizen after the World War II through the first reading book is examined in this article. It will be used a Bibliographic Research and Literature Reviews of all the textbooks and documents of the interesting topics at the Albanian National Archives and at the Albanian National and Regional Libraries The content of these textbooks surround different topics that aimed to realize these new national perspective: the construction of the great Albania and the new Albanian citizens under the general direction and overall commander Enver Hoxha: (1) the fighter and winner character of the Albanian people, the sense of freedom and of the new great nation; (2) educational character of the textbook stories through the usage of allegory; (3) the construction of gender role through the textbook stories; (4) the ideas of national belonging through the development of a new urban and rural place belonging.
\end{abstract}

Keywords: the Albanian textbooks, the Albanian citizens, place identity, World War II.

\section{Introduction}

Regardless of whether the political and academic debates in Albania are based on the date of liberation (Onuzi, 2005:28), the concepts and ideas of communism should be reconsidered and analyzed in their historical, sociological, psychological and pedagogical dimensions. It should be highlighted that the communist activity in Albania initiated from the beginning of the 20s, when a group of Albanian nationalists was encouraged and financed by Komintern and the Balkan Communist Federation. Even though the first Albanian communists were prepared in Moscow, around the 1924, they were fairly weak and disrupted when Italy invaded Albania in 1939. The Albanian socialist historiography inscribes that they demonstrated a heroic resistance, while in reality, as the American history writer Fischer argues, "exists rather few evidences supporting the idea that these groups arrive to be more than just the organization of a small number of protests" (Fischer, 1999: 172173). In reality, the attempts to establish a communist state were supported considerably even by Britain and USA, but the Albanian literature never transmitted these facts, distorting the real history by order of the communist leaders after the war (Hibbert, 1993:13). Only the communists groups of Albania could not be unified, as a result, thanks to the initiative of the communist group of Shkoder, it was decided to ask the help of the Yugoslavian communists, especially of Miladin Popoviç and Dushan Mugosha, who arrived to persuade the representatives of the three groups (those of Korça, Shkoder and Tirana) to meet at the beginning of November 1941(Hibbert, 1993:175).

In November 9, 1941 was established the Albanian Communist Party (Rama, 2005:71). The first step, the newly party had to undergo, was to present a program in front of the population expressing the core interest of all patriotic and social forces. This program should have opened concrete perspectives to the working and peasantry class, as the prevailing classes of the population (Shimani, 1987:14).

To win over the mind and heart of the people, the communist party used the activity of agitation, propaganda and the illustration of the programme to the simple people. To make it realizable, they used three kinds of propaganda: (1) the spoken propaganda- the dissemination of summon within families, close relatives together with the narration of events from the communist liberation war (Nano, 1982:38); (2) the written propaganda - the publication of summons, tracts and communications of the Albanian Communist Party generated as the first example of illegal press in Albania (Boriçi, 1986:5); (3) the artistic propaganda - patriotic songs sang primarily in schools by the youngsters and the staging of dramas with partisan characters (Nano, 1982:38). 
Under these circumstances, the Albanian Communist Party defined as a priority the construction of a political system, specifically that of the socialist order. There were undertaken fundamental reforms in three sectors: (1) legislation- proclaiming Albania as Popular Republic in 1946 (Fischer, 1999:344); (2) agrarian reform - the headship of National Liberation Council proclaimed the agrarian reform in 1945, where all demesne, olive fields, vineyards, agricultural premises and instruments became expropriated. The owners of the land were removed from every right on it (Gjeçovi, 2008:185); (3) reform in education- illiteracy was evident, with nearly $80 \%$ of the population. As a result, based on a circular in December 1944, urgent measures needed to be taken to disappear this national phenomenon: the opening of primary schools and courses for adults in the whole liberated territories was some of the initiatives (F. 490, D. 3.).

\subsection{The Scope of the Purpose}

The construction of the new Albanian citizen after the World War II through the first reading book is examined in this article.

\subsection{Methodology}

It will be used a Bibliographic Research and Literature Reviews of all the textbooks and documents of the interesting topics at the Albanian National Archives and at the Albanian National and Regional Libraries; also it will be used a Literature Reviews of the most reliable studies of psychology, sociology, European education historiography and pedagogy, through the analysis and the comparison of the available documents and books.

\subsection{Principal findings}

Since the French Revolution, the term "citizenship" has been used to describe political and social relationship among individuals, the civic community and the state. It is important to keep these basic points in mind when examining the educational prescription of turn-off-the-twentieth-century English elementary schooling, when "good citizenship" was increasingly prescribed as an important element of the working-class schoolchild's identity.

In the Albanian National Library is found a book entitled My first Reading. What attracts the attention, while flipping through, is the photo of a woman reading to her child. The content of the reading can be divided into some topics as: (1) the warlike character of the Albanian population, its sense of liberty and nation loving. The key words representing this communist attitude are: gun, enemy, partisan friends, courageous pioneer, flag, betrayal, traitor, motherland and freedom; (2) the educational character through allegory is evident in the story named "Serves him well", where the dog bites Gjenci because he did disturbed him (symbolizing the invading enemy); (3) the formation of identity is incredibly obvious in those stories, where the gender roles are clearly determined, for example in the stories "Leta and the Flowers", "Leta and Petriti" etc. is apparent the role of girls and boys. The girls play with flowers, take care of their younger brothers, and clean the house, while the boys help their fathers cutting wood or the partisans (First Reading, 1945:17-34). In fact, communist ideas produced for the family and the Albanian women had a devastating impact for whole generations (Frasheri, 2012:326); (4) the formation of a "place identity" through schools is presented in some stories, in which aspects of rural and urban life clash together. Importance is given to the building of cities, as a representation of something magnificent developing from the Albanians themselves.

\section{Discussion and Conclusions}

After the end of World War II, Albania experienced fundamental political and social changes of various kinds and to varying degrees. These changes heavily influenced the educational reality, including textbook stipulation and the new indoctrination of the masses at the first light of Enver Hoxha communist regime. Through this propose we aimed to describe briefly the traditionally pupils' first school textbook, exactly the textbook "Këndimi im i parë" (My first Reading) of 1945, which express the first psychopedagogical efforts to construct the new Albanian citizens after the "successful winner" of the war and the "devastation of enemy".

To illustrate better this new educational reality it has been used important documents from the Albanian national library and archives. The content of these textbooks surround different topics that aimed to realize these new national perspective: the construction of the great Albania and the new Albanian citizens under the general direction and overall 
commander Enver Hoxha: (1) the fighter and winner character of the Albanian people, the sense of freedom and of the new great nation; (2) educational character of the textbook stories through the usage of allegory - hidden meanings through symbolic figures, actions, imagery, and events, which together create the moral, spiritual or political meaning that the author wishes to communicate; (3) the construction of gender role through the textbook stories; (4) the ideas of national belonging through the development of a new urban and rural place belonging.

We can recommended further study about the themes that emerged in this article, and in specific mode how is describe in Childs' books the process of place identity formation, because this remain an unknown topic for the Albanian literature.

\section{References}

Boriçi H. (1986).Teoria dhe praktika e shtypit popullor. Redaksia dhe puna e gazetarit. [Theory and practice of the popular press. Editorial and work of journalist]. Tiranë:: "Mihal Duri".

Fischer, B. (1999). Shqipëria gjatë luftës 1939-1945. [The Albania during the War 1939-1945]. Tiranë: Çabej.

Gjeçovi Xh. (ED). (2008). Historia e popullit shqiptarë IV. Shqiptarët gjatë Luftës së Dytë Botërore dhe pas saj 1939-1990. [History of the Albanian people IV. Albanians during World War II and its aftermath 1939-1990]. Tiranë: Toena.

Hibbert, R. (1993). Fitorja e hidhur. Lufta Nacionalçlirimtare e Shqipërisë. [Albania's National Liberation Struggle. The bitter victory]. Tiranë: "A.Z. Çajupi".

Komiteti Antifashist Nacionalçlirimtare. Dikasteri i Arsimit, 2/10/1944, F. 490, D. 3.

Nano, Th. (19822). Agjitacioni e propaganda gjatë Luftës Nacionalçlirimtare. [Agitation and propaganda during the National Liberation War], Tiranë: "8 Nëntori".

Onuzi, S. (2005). Data e çlirimit. 29 Nëntor 1944. [The Liberation date. 29 Nëntor 1944]. Tiranë: Toena.

Rama, F. (2005). Dukuri arsimore gjatë Luftës së Dytë Botërore në Shqipëri. [Educational phenomenon during World War II in Albania]. Tiranë: Argeta.

Shimani, L. (1987). Lidhjet e Partisë Komuniste te Shqipërisë me masat popullore. [The connections of Albania's Communist Party with the masses]. Tiranë: "Mihal Duri".

Tanush Frashëri, T. (2012). Ali Këlcyra. Shkrime për historinë e Shqipërisë. [Ali Kelcyra. Letters about the history of Albania]. Tiranë: Onufri. 
